Keywords: Next Generation Solvent, MCU, CSSX, DWPF

Retention: Permanent

\title{
Impact of the Next Generation Solvent on DWPF CPC Processing
}

J.D. Newell

February 2013

Savannah River National Laboratory Savannah River Nuclear Solutions, LLC Aiken, SC 29808

Prepared for the U.S. Department of Energy under contract number DE-AC09-08SR22470. 
SRNL-STI-2013-00066

Revision 0

\section{DISCLAIMER}

This work was prepared under an agreement with and funded by the U.S. Government. Neither the U.S. Government or its employees, nor any of its contractors, subcontractors or their employees, makes any express or implied:

1. warranty or assumes any legal liability for the accuracy, completeness, or for the use or results of such use of any information, product, or process disclosed; or

2. representation that such use or results of such use would not infringe privately owned rights; or

3. endorsement or recommendation of any specifically identified commercial product, process, or service.

Any views and opinions of authors expressed in this work do not necessarily state or reflect those of the United States Government, or its contractors, or subcontractors.

\section{Printed in the United States of America}

Prepared for

U.S. Department of Energy 


\section{REVIEWS AND APPROVALS}

AUTHORS:

J.D. Newell, Process Engineering Technology

Date

TECHNICAL REVIEW:

M.E. Stone, Process Engineering Technology

Date

APPROVAL:

C.C. Herman, Manager

Date

Process Engineering Technology

S.L. Marra, Manager

Date

Environmental \& Chemical Process Technology Research Programs

E.J. Freed, Manager

Date

SRR Engineering 


\section{EXECUTIVE SUMMARY}

As part of the Actinide Removal Process (ARP)/Modular Caustic-side Solvent Extraction Unit (MCU) Life Extension Project, a next generation solvent (NGS) and new strip acid will be deployed. Processing will begin with a blend of the current solvent and the NGS. Compositional changes in the NGS solvent and blending with the current solvent require review of previously performed work to determine if additional experimental work is required to address any impacts to the Defense Waste Processing Facility (DWPF) Chemical Process Cell (CPC). The composition change involved the substitution of the $N, N^{\prime}$-dicyclohexyl- $N$ "-isotridecylguanidine LIX $^{\circledR} 79$ guanidine suppressor with $N, N^{\prime}, N$ ”-tris (3,7-dimethyloctyl) guanidine (TiDG) guanidine suppressor.

The Savannah River National Laboratory (SRNL) was requested by DWPF to evaluate any impacts to offgas generation, solvent buildup or carryover, chemical, thermal, and radiolytic stability of the blended and pure TiDG based NGS. Previous work has been performed by SRNL to evaluate impacts to CPC processing using the next generation solvent containing LIX $^{\circledR} 79$ suppressor with boric acid strip effluent.

Based on previous experimental work and current literature, the following conclusions are made for processing in the CPC:

- No mechanism for a change in the catalytic hydrogen evolution in the CPC was identified for the NGS TiDG based solvent.

- The transition from the LIX ${ }^{\circledR} 79$ based suppressor to the TiDG based suppressor is not expected to have any impact on solvent or Isopar ${ }^{\circledR} \mathrm{L}$ accumulation.

- Transitioning from the current solvent to the TiDG based NGS is not expected to have an impact on solvent carryover or partitioning.

- No changes to the chemical stability of the solvent in the CPC process are expected.

- No changes to the thermal stability of the solvent in the CPC process are expected.

- A "worst case" scenario was examined in which all of the hydrogen atoms from the TiDG based NGS and blended solvent form hydrogen gas in the Sludge Receipt and Adjustment Tank (SRAT) as a result of radiolytic degradation. This represented a $\sim 4 \%$ increase in the volume percent hydrogen in the SRAT.

Given the chemical similarity and very low concentrations of the suppressor, it is not recommended that additional experimental work be performed to qualify any impacts to the DWPF CPC from the change in suppressor or the revised value for partitioning of the suppressor into the strip effluent. 


\section{TABLE OF CONTENTS}

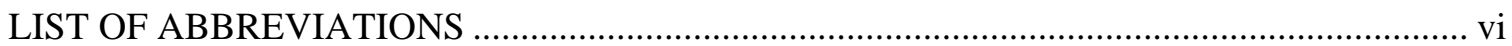

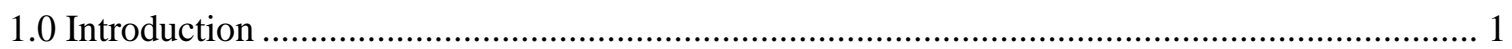

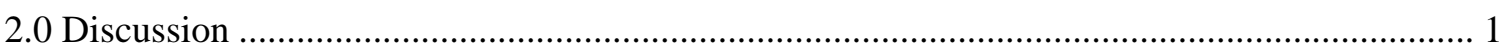

2.1 Comparison of the NGS and Previously Studied Solvents ................................................... 1

2.2 CPC Process Impact for TiDG based NGS and Blended Solvent ....................................... 2

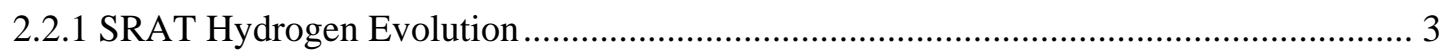

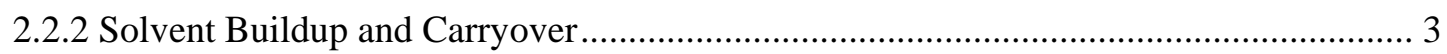

2.3 Stability of TiDG based NGS and Blended Solvent under CPC Conditions ......................... 3

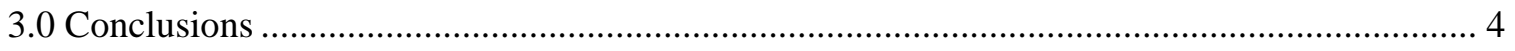

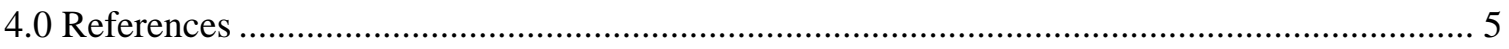




\section{LIST OF ABBREVIATIONS}

$\begin{array}{ll}\text { ARP } & \text { Actinide Removal Process } \\ \text { CPC } & \text { Chemical Processing Cell } \\ \text { CSSX } & \text { Caustic Side Solvent Extraction } \\ \text { DF } & \text { Decontamination Factor } \\ \text { DWPF } & \text { Defense Waste Processing Facility } \\ \text { MCU } & \text { Modular Caustic-side solvent extraction Unit } \\ \text { MWWT } & \text { Mercury Water Wash Tank } \\ \text { NGS } & \text { Next Generation Solvent } \\ \text { SB } & \text { Sludge Batch } \\ \text { SMECT } & \text { Slurry Mix Evaporator Condensate Tank } \\ \text { SPF } & \text { Saltstone Processing Facility } \\ \text { SRAT } & \text { Sludge Receipt and Adjustment Tank } \\ \text { SRNL } & \text { Savannah River National Laboratory } \\ \text { TTQAP } & \text { Task Technical and Quality Assurance Plan } \\ \text { TTR } & \text { Technical Task Request }\end{array}$




\subsection{Introduction}

The ARP/MCU project includes activities required to support extended operations of ARP/MCU to remove cesium and actinides/strontium from dissolved salt cake waste and send the remaining low-activity decontaminated salt solution as feed to the Saltstone Processing Facility (SPF). The extracted cesium and actinide/strontium are sent to the DWPF for immobilization into a borosilicate glass matrix. As part of the ARP/MCU NGS project, a next generation solvent (NGSMCU) and a new strip acid will be deployed. The NGS-MCU is comprised of the following four components [1]:

- Extractant: MaxCalix, 1,3-alt-25,27-Bis(3,7 dimethyloctyloxy) calix[4]-arenebenzocrown-6, $0.05 \mathrm{M}$

- Modifier: Cs-7SB, 1-(2,2,3,3-Tetrafluoropropoxy)-3-(4-sec-butylphenoxy) -2-propanol, $0.50 \mathrm{M}$ or

- Suppressor: TiDG, N,N',N”-tris (3,7-dimethyloctyl) guanidine, 0.003M

- Diluent: Isopar ${ }^{\circledR} \mathrm{L}, \mathrm{C}_{12}$-isoparaffinic hydrocarbon, balance

The solvent currently being used has a different extractant and suppressor [2]:

- Extractant: BOBCalixC6, calix[4]arene-bis(tert-octyl benzo-crown-6), $0.007 \mathrm{M}$

- Modifier: Cs-7SB, 1-(2,2,3,3-tetrafluoropropoxy)-3-(4-sec butylphenoxy) -2-propanol, $0.75 \mathrm{M}$

- Suppressor: TOA, tri-n-octylamine, $0.003 \mathrm{M}$

- Diluent: Isopar ${ }^{\circledR} \mathrm{L}, \mathrm{C}_{12}$-isoparaffinic hydrocarbon, balance

Along with the solvent, the MCU strip solution will also be changed from dilute nitric acid currently being used with the current solvent to dilute boric acid $(0.01 \mathrm{M})$ for the NGS-MCU.

A blended composition of the current solvent and NGS is represented by the following composition [1]:

- Extractant: MaxCalix (0.0465 M) and BobCalixC6 (0.0035 M)

- Modifier: Cs-7SB, $0.5 \mathrm{M}$

- Suppressor: TiDG (0.003 M) and TOA (0.0015 M)

- Diluent: Isopar ${ }^{\circledR} \mathrm{L}$, balance

There are three sub-tasks in Task \#1, as presented in the Technical Task Request (TTR) [1]; (1) CPC Process Impact for TiDG based NGS and a blend of TiDG based NGS and the current solvent, (2) stability of TiDG based NGS and blended solvent under DWPF CPC operating conditions, and (3) material compatibility studies.

In response to the TTR, a Task Technical and Quality Assurance Plan (TTQAP) was issued by the SRNL which outlined the technical approach to be used to meet programmatic objectives [2].

\subsection{Discussion}

\subsection{Comparison of the NGS and Previously Studied Solvents}

Experiments conducted in 2005 utilized a MCU solvent comprised of 0.007 M BobCalixC6, 0.75 M Cs-7SB, and 0.003 M TOA in the diluent Isopar ${ }^{\circledR}$ L (69.14 wt\%) [3]. This solvent was tested 
in simulated SRAT cycles at a concentration of $500 \mathrm{ppm}$ (mg solvent $/ \mathrm{kg}$ strip effluent). At this solvent concentration, the Isopar ${ }^{\circledR} \mathrm{L}$ concentration is calculated to be $346 \mathrm{ppm}$. The MCU stream did not appear to impact nitrite destruction, hydrogen generation, mercury reduction, or foaming.

Because of concerns of solvent partitioning, additional tests were conducted in 2006 [4]. For the first SRAT run of this series, the organic solvent used in the testing was the same as that used in the 2005 testing and contained the four organic components $(0.007 \mathrm{M}$ BOBCalixC6, $0.75 \mathrm{M}$ Cs7SB modifier, $0.003 M$ tri-n-octylamine (TOA), and the diluent Isopar ${ }^{\circledR} \mathrm{L}$ ). This solvent was tested in simulated SRAT cycles at a concentration of $239 \mathrm{ppm}$ (mg solvent/kg strip effluent). At this solvent concentration, the Isopar ${ }^{\circledR} \mathrm{L}$ concentration is calculated to be $165 \mathrm{ppm}$. Results from these tests indicated the MCU stream did not impact nitrite destruction, hydrogen generation, mercury reduction, offgas concentration, nitrite to nitrate conversion, manganese reduction, $\mathrm{pH}$ profiles, or foaming.

Experiments were conducted in 2011 that utilized a revised MCU solvent comprised of $0.050 \mathrm{M}$ MaxCalix, 0.50 M Cs-7SB, $0.003 \mathrm{M} \mathrm{LIX}^{\circledR} 79$ guanidine, with the balance ( 74 wt\%) being Isopar $^{\circledR} \mathrm{L}$ [5]. This solvent was tested in simulated SRAT/SME cycles at a concentration of 125 $\mathrm{ppm}$ (mg solvent $/ \mathrm{kg}$ strip effluent). At this concentration of solvent, the Isopar ${ }^{\circledR} \mathrm{L}$ fraction is calculated to be $93 \mathrm{ppm}$ (mg Isopar ${ }^{\circledR} \mathrm{L} / \mathrm{kg}$ strip effluent). Results indicated no impact to processing or offgas generation. Identical experiments were conducted using the previously studied solvent composition from 2005 and 2006 with similar results.

In 2011, SRNL was also asked to publish a position on the effect of blending the baseline solvent comprised of BOBCalixC6, TOA and nitric acid strip effluent with that of a revised composition comprised of MaxCalix, LIX ${ }^{\circledR} 79$ guanidine, and boric acid strip effluent [6]. SRNL researchers determined that there would be no deleterious effects from mixing baseline and revised solvents on DWPF CPC processing, given that 1) the two solvents are miscible over the range of expected concentrations, 2) there was little or no difference in processing between the two solvents, and 3) the two solvents were chemically similar.

The previous studies mentioned above evaluated components of both the pure NGS and baseline solvent at higher concentrations than those being considered for this evaluation: $118 \mathrm{mg}$ solvent/kg strip effluent (87 mg Isopar ${ }^{\circledR} \mathrm{L} / \mathrm{kg}$ strip effluent). The concentration of extractant, modifier, and suppressor of the NGS and baseline solvents in the strip effluent will be less than, or equal to, the concentrations previously studied. For this evaluation, the LIX ${ }^{\circledR} 79$ guanidine suppressor used in previous experiments is being replaced with the TiDG suppressor. As previous research has shown no impact to DWPF CPC processing with the replacement of TOA with LIX ${ }^{\circledR} 79$ guanidine, and given the chemical similarity between LIX ${ }^{\circledR} 79$ guanidine and TiDG, no negative impacts are expected from replacing TOA with TiDG or from any blend of the two solvents.

Isopar ${ }^{\circledR} \mathrm{L}$ continues to be the only flammable solvent component at SRAT operating temperatures. The vapor pressures of the other solvent components continue to be too low to cause concern. This applies to either the NGS or baseline solvent, or any mixture of the two.

\subsection{CPC Process Impact for TiDG based NGS and Blended Solvent}

The Next Generation Caustic Side Solvent Extraction (NG-CSSX) process was developed in order to improve the waste decontamination factor (DF) and waste throughput in the Caustic Side Solvent Exchange (CSSX) process [7-9]. To improve the cesium DF, a solvent containing 50 $\mathrm{mM}$ MaxCalix, $0.5 \mathrm{M}$ of modifier Cs-7B, $3 \mathrm{mM}$ of guanidine suppressor in Isopar $^{\circledR} \mathrm{L}$ was 
investigated [10]. Although the concentration of suppressor is low, it is essential for stripping. In the current process, TOA is used as the suppressor. This suppressor was found to be less effective with the aqueous boric acid used in the CSSX process [11]. For this reason, a more lipophilic guanidine, LIX ${ }^{\circledR} 79$, was chosen. Process testing has shown, however, that the partition ratio $P_{\text {Gua }}$ of LIX $^{\circledR} 79$ with the $10 \mathrm{mM}$ strip solution to be unexpectedly low (35 \pm 8 ) [12]. A partition ratio of $P_{\text {Gua }}>1000$ is desired to avoid depletion of the suppressor [13].

Previous work involving simulated sludge, as well as the associated byproduct stream from MCU containing the LIX ${ }^{\circledR} 79$ based NGS and strip acid at bounding concentrations was considered against the modified TiDG based NGS to determine whether any impact to the CPC process is likely. Impacts to be considered are whether there are any expected differences in hydrogen evolution in the SRAT, solvent buildup in the SRAT, and solvent carryover between the two guanidine based solvents. Evaluations are based on a maximum Isopar ${ }^{\mathbb{B}}$ L concentration of 87 ppm in the strip effluent [14].

\subsubsection{SRAT Hydrogen Evolution}

Catalytic hydrogen evolution in the SRAT is due to the use of formic acid in the presence of noble metals (rhodium, ruthenium, and palladium). In previous NGS studies, hydrogen offgas data was not affected by the implementation of the LIX ${ }^{\circledR} 79$ guanidine suppressor [5]. Given the low concentration of the suppressor and similarity in chemical structure, it is not expected that transitioning to the TiDG suppressor will impact hydrogen evolution.

\subsubsection{Solvent Buildup and Carryover}

Previous experimental work performed in 2006 using the current solvent demonstrated that a majority of the Isopar ${ }^{\circledR} \mathrm{L}$ was found in the offgas [4]. The offgas from the runs was collected on activated carbon passive sampling tubes to adsorb any organics given off during the process. The SRAT equipment was disassembled, rinsed, and samples analyzed to determine where the solvent remained. This work was repeated using the LIX ${ }^{\circledR} 79$ suppressor, giving similar results. It was determined that approximately $90 \%$ of the Isopar ${ }^{\circledR}$ L exited the offgas and was captured on the carbon tubes [5]. Of the modifier recovered, about half was found in the SRAT vessel with the rest partitioned between the Mercury Water Wash Tank (MWWT) and Slurry Mix Evaporator Condensate Tank (SMECT). The role of the suppressor does not appear to have any impact on solvent accumulation. Substituting LIX ${ }^{\circledR} 79$ for the TOA suppressor had no effect on solvent accumulation or partitioning. Transitioning to the TiDG guanidine should have no impact as well.

\subsection{Stability of TiDG based NGS and Blended Solvent under CPC Conditions}

When the TiDG based NGS and boric acid strip effluent are deployed, processing will begin with a blend of the TiDG based NGS and the current TOA based solvent. The blend will eventually transition to $100 \%$ TiDG based NGS. A review of previous experimental work performed using the LIX $^{\circledR} 79$ based NGS and available literature was conducted to determine any change in the stability of the TiDG based NGS and blended solvent in the DWPF chemical and radiolytic conditions.

There are limited streams with which the solvent can come into contact during DWPF processing. Compositionally, the change from the LIX ${ }^{\circledR} 79$ suppressor to TiDG represents a minor change, and given the chemical similarity between the MaxCalix and BOBCalix, there is no expected change in any reaction of the TiDG based NGS solvent with sludge, concentrated nitric and formic acids, concentrated sodium hydroxide and agitator oil, with respect to the current solvent. Any blend of the two solvents is not expected to have any different reaction with respect to the current solvent. 
Thermal stability tests of the TiDG based NGS solvent were performed at ORNL [13]. It was determined that the new solvent performed equally as well as the LIX ${ }^{\circledR} 79$ based NGS solvent under identical thermal conditions. It is not expected that any blend of the two solvents would prove otherwise.

For the LIX ${ }^{\circledR} 79$ based NGS, a "worst case” scenario was examined in which all of the hydrogen atoms from the NGS form hydrogen in the SRAT as a result of radiolytic conditions. Calculations were performed to determine the impact of the LIX ${ }^{\circledR} 79$ based NGS on hydrogen generation in the SRAT [15]. Assuming all the hydrogen from the LIX ${ }^{\circledR} 79$ based NGS is released in 1 hour and a SRAT air purge rate of $230 \mathrm{scfm}$, the volume percent hydrogen in the SRAT from the degradation of the solvent would be 2.124\%. Substituting compositions for the pure TiDG based NGS and blended solvents including a 6 ppm TiDG partitioning into the strip effluent, the volume percent hydrogen is calculated to be $2.211 \%$ and $2.201 \%$, respectively. This $\sim 4 \%$ change does not represent an appreciable increase.

\subsection{Conclusions}

Previous experimental work and available literature were examined to determine if the changes represented by the new TiDG suppressor based NGS and the blended solvent have any impact on processing in the DWPF Chemical Process Cell.

From this review, the following conclusions are made:

- No mechanisms for catalytic hydrogen evolution in the CPC are expected from the change in the NGS solvent.

- The transition from the TOA suppressor to TiDG is not expected to have an impact on solvent or Isopar ${ }^{\circledR} \mathrm{L}$ accumulation.

- Transitioning from the current solvent to the TiDG based NGS is not expected to have an impact on solvent carryover or partitioning.

- No changes to the chemical stability of the solvent in the CPC process are expected.

- No changes to the thermal stability of the solvent in the CPC process are expected.

- A "worst case" scenario was examined in which all of the hydrogen atoms from the TiDG based NGS and blended solvent form hydrogen gas in the SRAT as a result of radiolytic conditions. This represented a $\sim 4 \%$ increase in the volume percent hydrogen in the SRAT as compared to the current solvent.

Given the chemical similarity and very low concentrations of the guanidine examined in previous LIX $^{\circledR} 79$ based NGS studies and the guanidine in the new TiDG based NGS, additional experimental work is not recommended to qualify any impacts to the DWPF CPC. 
SRNL-STI-2013-00066

Revision 0

\subsection{References}

1. Samadi, A. Testing for ARP/MCU NGS Project-DWPF; HLW-DWPF-TTR-2010-00045, Rev. 1; 2011.

2. Newell, J.D.; Daniel, W.E. Task Technical and Quality Assurance Plan for Sludge Batch 8 Simulant Flowsheet Studies; SRNL-RP-2011-01679, Rev. 2; Savanah River National Laboratory: Aike, SC, 2013.

3. $\quad$ Baich, M.A.; Herman, C.C.; Eibling, R.E.; Williams, M.F.; Smith, F.G. Sludge Batch 4 Simulant Flowsheet Studies with ARP and MCU: Impact of MCU Organics; WSRC-TR2005-00230; Savannah River National Laboratory: Aiken, SC, 2005.

4. Lambert, D.P.; Williams, M.F.; Crump, S.L.; Eibling, R.E.; White, T.L.; Best, D.R. DWPF Flowsheet Studies with Simulants to Determine MCU Solvent Build-up in Continuous Runs; WSRC-TR-2006-00154; Savannah River National Laboratory: Aiken, SC, 2006.

5. Newell, J.D.; Peeler, D.K.; Edwards, T.B.; Hay, M.S.; Stone, M.E. DWPF Flowsheet Studies with Simulant to Determine the Impact of Next Generation Solvent on the CPC Process and Glass Formulation; SRNL-STI-2011-00273; Savannah River National Laboratory: Aiken, SC, 2011.

6. Newell, J.D. Effect of Blended Baseline and Next Generation Solvent on DWPF CPC Processing; SRNL-L3100-2011-00152; Savannah River National Laboratory: 2011.

7. Delmau, L.H.; Birdwell, J.F.; Bonnesen, P.V.; Foote, L.J.; Haverlock, T.J.; Klatt, L.N.; Lee, D.L.; Leonard, R.A.; Levitskaia, T.G.; Maskarinec, M.P.; Moyer, B.A.; Sloop, F.V.; Tomkins, B.A. Caustic-Side Solvent Extraction: Chemical and Physical Properties of the Optimized Solvent; ORNL/TM-2002/190; Oak Ridge National Laboratory: 2002.

8. Delmau, L.H.; Birdwell, J.F.; Bonnesen, P.V.; Moyer, B.A., Use of Macrocycles in Nuclear-Waste Cleanup: A Real-World Applicaton of a Calixcrown in Technology for the Separation of Cesium. Edited by K. Gloe. Springer, 2005.

9. Moyer, B.A.; Alexandratos, S.D.; Bonnesen, P.V.; Brown, G.M.; Caton, J.E.; Delmau, L.H.; Duchein, C.R.; Haverlock, T.J.; Levitskaia, T.G.; Maskarinec, M.P.; Sloop, F.V.; Stine, C.L. Caustic-Side Solvent Extraction Chemical and Physical Properties: Progress in FY2000 and FY2001; ORNL/TM-2001/285; Oak Ridge National Laboratory: 2002.

10. Moyer, B.A.; Bonnesen, P.V.; Delmau, L.H.; Sloop, F.V.; Williams, N.J.; Birdwell, J.F.; Lee, D.L.; Leonard, R.A.; Fink, S.D.; Peters, T.B.; Geeting, M.W., "Development of the Next-Generation Caustic-Side Solvent Extracton (NG-CSSX) Process for Cesium Removal from High-Level Tank Waste-11346," Proceedings Waste Management 2011 Conference, Phoenix, AZ, (2011).

11. Delmau, L.H.; Birdwell, J.F.; Bonnesen, P.V.; Ladd, C.J.; Moyer, B.A.; Stoner, E.L.; Lee, D.L.; Sloop, F.V., in "Proc. International Solvent Extraction Conference ISEC 2011" (V. F. and B. A. Moyer, eds.). Gecamin, Santiago, Chile, 2011. 
12. Duncan, N.C.; Roach, B.D.; Williams, N.J.; Bonnesen, P.V.; Rajbanshi, A.; Moyer, B.A., "N,N'-Dicyclohexyl-N'-Isotridecylguanidine as Suppressor for the Next Generation Caustic-Side Solvent Extrction (NG-CSSX) Process," Sep. Sci. Technol., 47 2074-87 (2012)

13. Moyer, B.A.; Delmau, L.H.; Duncan, N.C.; Ensor, D.D.; Hill, T.G.; Lee, D.L.; Roach, B.D.; Sloop, F.V.; Williams, N.J. Recommended Guanidine Suppressor for the Next Generation Caustic-Side Solvent Extraction Process; ORNL/TM-2012/625; Oak Ridge National Laboratory: 2013.

14. Shafer, A.R. Waste Acceptance Criteria for Sludge, ARP, and MCU Process Transfers to 512-S and DWPF; X-SD-G-00008, Rev 9; 2012.

15. Hay, M.S. Literature Review of the Radiation Stability of the Next-Generation CausticSide Solvent Extraction System (NG-CSSX); SRNL-L3100-2011-00067; Savannah River National Laboratory: Aiken, SC, 2011. 


\section{Distribution:}

E. N. Hoffman, 999-W

D. R. Click, 999-W

C. C. Herman, 999-W

D. K. Peeler, 999-W

M. E. Stone, 999-W

J. D. Newell, 999-W

R. K. Leugemeors, 992-5W

S. L. Marra, 773-A

S. D. Fink, 773-A

F. M. Pennebaker, 773-42A

W. R. Wilmarth, 773-A

D. T. Herman, 735-11A

P. R. Jackson, 703-46A

D. P. Lambert, 999-W

T. B. Peters, 773-42A

A. S. Choi, 773-42A

F. G. Smith, 703-41A

J. F. Iaukea, 704-30S

J. W. Ray, 704-S

D. C. Sherburne, 704-S

D. C. Koopman, 999-W

J. M. Bricker, 704-27S

T. L. Fellinger, 704-26S

A. Samadi, 704-27S

E. W. Holtzscheiter, 704-15S
E. J. Freed, 704-56H

D. J. Martin, 241-152H

R. H. Spires, 241-156H

E. A. Brass, 249-8H

J. P. Schwenker, 766-H

K. H. Subramanian, 241-156H

P. J. Ryan, 210-S

T. B. Peters, 773-42A

J. M. Pareizs, 773-A

J. R. Zamecnik, 999-W 